\title{
Serine/Threonine Kinase Inhibitor
}

National Cancer Institute

\section{Source}

National Cancer Institute. Serine/Threonine Kinase Inhibitor. NCI Thesaurus. Code

C61074.

Any substance that inhibits serine/threonine protein kinase, an enzyme that phosphorylates the hydroxyl group of serine or threonine on various proteins in various signaling cascades. Inhibition of serine/threonine protein kinase can inhibit cell proliferation and induce apoptosis. 